DOI https://doi.org/10.30929/2307-9770.2019.07.03.11

UDC 37.016: 004.896(477)

\title{
Teaching of the Educational Robotics in Ukrainian Schools: the Ways of Implementation
}

\author{
Strutynska 0.*, Vasyliuk A. \\ National Dragomanov Pedagogical University, Kyiv, Ukraine
}

Received: 10.09 .2019

Accepted: 22.09 .2019

\begin{abstract}
The paper is considered of the issues of determining the ways of implementation of the educational robotics in Ukrainian schools. The present research describes of the educational robotics as a powerful tool for STEM education; its interdisciplinary links, including STEM subjects, have been analyzed. Analysis of the current state of robotics development as an applied field has shown its intensive development. As a consequence, there is an increasing demand for specialists in the robotics industry, as there is already an urgent need for specialists to plan, design and programming robots. Also, it is revealed of the increasing of the robotics popularity as an educational trend in Ukraine and in the world. Such basic methods were used in present research as analysis of the development state of the educational robotics in Ukraine, searching of relevant data for determining of learning process of the secondary education institutions, etc. During the current work it was found out that one of the ways to increase of the competitiveness of our country, in particular in the IT industry, is to implement into the school curriculum of the subjects related to modern ICTs, in particular educational robotics. An analysis of the interdisciplinary links of the educational robotics has shown that it is an interdisciplinary subject, which is at the intersection a lot of the natural science and technical fields. In particular, teaching of the educational robotics enables to the students to solve real life problems that require of the knowledge of STEM subjects. These considerations also confirm of the timeliness and relevance of the separation of robotics into a separate area and the implementation into the learning process of Ukrainian schools of the separate school subject - the school course of the robotics - in the future. The authors propose the 5 main directions of implementation of the educational robotics in the learning process at schools, which can be further defined as modules of the future school course of the robotics. Such steps will allow to prepare quickly and qualitatively of the children for the modern conditions of intensive IT development, which, in turn, will enable them to become competitive specialists in the IT industry in the future.

Key words: robotics; educational robotics; interdisciplinary links of the educational robotics, STEM education.
\end{abstract}

\section{Навчання освітньої робототехніки в українських школах: напрями впровадження}

\author{
Струтинська О. В., Василюк А. Д.
}

Національний педагогічний університет імені М.П. Драгоманова, Київ, Україна

\begin{abstract}
Анотація. Стаття присвячена питанням визначення напрямів впровадження освітньої робототехніки в заклади шкільної освіти в Україні. В дослідженні охарактеризовано освітню робототехніку як потужний інструмент STEM-освіти; проаналізовано їі міжпредметні зв'язки, зокрема із STEM-предметами. Аналіз сучасного стану розвитку робототехніки як прикладної галузі показав її інтенсивний розвиток. Як наслідок, спостерігається зростання попиту на спеціалістів робото-технічної галузі, оскільки вже зараз існує нагальна потреба у фахівцях для розробки, конструювання та програмування роботів. Також виявлено підвищення популярності робототехніки як освітнього тренду в Україні та світі. В процесі даного дослідження використовувалися такі основні методи, як аналіз стану розвитку освітньої робототехніки в Україні, пошук релевантних даних для визначення умов впровадження освітньої робототехніки в навчальний процес закладів середньої освіти та ін. В ході роботи з'ясовано, що одним із шляхів підвищення конкурентоспроможності нашої країни, зокрема в ITгалузі, $€$ введення до шкільної програми предметів, пов'язаних з сучасними ІКТ, зокрема освітньої робототехніки. Аналіз міжпредметних зв'язків освітньої робототехніки показав, що вона є міждисциплінарним предметом, який знаходиться на стику багатьох природничо-наукових та технічних напрямів. Зокрема, навчання освітньої робототехніки надає можливість учням і студентам вирішувати реальні життві проблеми,
\end{abstract}

Corresponding Author: Strutynska Oksana Vitaliivna. Tел. 067-145-64-07. E-mail: o.v.strutynska@npu.edu.ua National Dragomanov Pedagogical University, Pyrogova Str., 9, Kyiv, Ukraine, 01601.

Відnовідальний автор: Струтинська Оксана Віталіївна. Тел. 067-145-64-07. E-mail: o.v.strutynska@npu.edu.ua Національний педагогічний університет імені М. П. Драгоманова, вул. Пирогова, 9, м. Київ, Україна, 01601. 
які потребують знань STEM-предметів. Ці міркування також підтверджують своєчасність та актуальність виділення робототехніки в окрему предметну галузь та введення у майбутньому в навчальний процес українських шкіл окремого навчального предмету - шкільного курсу робототехніки. Авторами запропоновано 5 основних напрямів впровадження освітньої робототехніки у навчальний процес закладів шкільної освіти, які в подальшому можуть бути визначені як модулі майбутнього шкільного курсу робототехніки. Такі кроки дозволять швидко і якісно підготувати дітей до сучасних умов інтенсивного розвитку інформаційних технологій, що, в свою чергу, надасть їм можливість в майбутньому стати конкурентоспроможними фахівцями ІТ-індустрії.

Ключові слова: робототехніка, освітня робототехніка, міжпредметні зв'язки освітньої робототехніки, STEMосвіта.

\title{
Обучение образовательной робототехнике в украинских школах: направления внедрения
}

\author{
Струтинская О. В., Василюк А. Д. \\ Национальный педагогический университет имени М.П. Драгоманова, Киев, Украина
}

\begin{abstract}
Аннотация. Статья посвящена вопросам определения направлений внедрения образовательной робототехники в школы Украины. В исследовании охарактеризована образовательная робототехника как мощный инструмент STEM-образования; проанализированы ее межпредметные связи, в частности со STEMпредметами. Анализ современного состояния развития робототехники как прикладной отрасли показал ее интенсивное развитие. Как следствие, наблюдается рост спроса на специалистов робототехнической отрасли, поскольку уже сейчас существует насущная потребность в специалистах для разработки, конструирования и программирования роботов. Также выявлено повышение популярности робототехники как образовательного тренда в Украине и мире. В процессе данного исследования использовались следующие основные методы, такие как анализ развития образовательной робототехники в Украине, поиск релевантных данных для определения условий внедрения образовательной робототехники в учебный процесс украинский школ и др. В ходе работы выяснилось, что одним из путей повышения конкуретноспособности нашей страны, в частности в ИТ-отрасли, является введение в школьную программу предметов, связанных с современными ИКТ, в частности образовательной робототехники. Анализ межпредметных связей образовательной робототехники показал, что она является междисциплинарным предметом, который находится на стыке многих естественнонаучных и технических направлений. В частности, обучение образовательной робототехнике позволяет ученикам и студентам решать реальные жизненные проблемы, требующие знаний STEM-предметов. Эти соображения также подтверждают своевременность и актуальность выделения робототехники в отдельную предметную область и введение в будущем в учебный процесс украинских школ отдельного предмета - школьного курса робототехники. Авторами предложено 5 основных направлений внедрения образовательной робототехники в учебный процесс украинских школ, которые в дальнейшем могут быть определены как модули будущего школьного курса робототехники. Такие шаги позволят быстро и качественно подготовить детей к современным условиям интенсивного развития информационных технологий, что, в свою очередь, даст им возможность в будущем стать конкурентоспособными специалистами ИТ-индустрии.
\end{abstract}

Ключевые слова: робототехника, образовательная робототехника, межпредметные связи образовательной робототехники, STEM-образование.

\section{Bcmyn}

Постановка проблеми. В наш час сучасні інфрормаційно-комунікаційні технології інтенсивно впроваджуються в усі сфери життя людини: промисловість, військова, космічна, автомобільна галузі, авіація, медицина, освіта, сфера обслуговування, побут тощо. Таке впровадження потребує велику кількість кваліфікованих IT-фрахівців. Як наслідок, сучасна освіта має швидко адаптуватись до потреб суспільства і надавати учням такі знання, які в майбутньому дозволили б їм стати конкурентоспроможними фахівцями IT-індустрії. Цілком очевидно, що закладати фундамент відповідних навичок і компетентностей необхідно з початкової та середньої школи.

Однією з таких IT-галузей, які на теперішній час швидко розвиваються, $€$ робототехнічна. Сучасний стан розвитку робототехніки як прикладної галузі показує [1]:

- зростання обсягу виробництва промислових роботів (за даними Міжнародної федерації робототехніки (IFR - International Federation of Robotics) загальний обсяг продажів промислових роботів подвоївся з 2013 по 2017 рр.) [2]; 
- впровадження робототехнічних механізмів і комплексної автоматизації виробництва в багатьох галузях суспільної діяльності (промисловість, військова, космічна, автомобільна галузі, авіація, медицина, сфера обслуговування, побут тощо) [3, С. 181; 4, C. vii];

- розвиток так званих "розумних фабрик" (Smart Factories) як однієї із складових концепції "Industry 4.0", головною ідеєю якої є розвиток та інтеграція автоматизованого виробництва, обміну даних і виробничих технологій в єдину саморегульовану систему з мінімальним або взагалі відсутнім втручанням людини у виробничий процес. Smart Factory - це завод, обладнання на якому автоматизоване, управляється комп'ютером і може отримувати зворотні дані про стан об'єкта у фрізичному просторі за допомогою сенсорів [5, С. 8, С. 10];

- прискорення швидкості автоматизації виробництва у найближчі 6 років (за даними досліджень Всесвітнього економічного форуму (WEF - World Economic Forum) до 2025 р. значно зміниться співвідношення у розподілі праці "людина-робот" у бік роботизації, рис. 1) [4];

- збільшення інтересу найбільших світових компаній до робототехнічних стартапів. Зокрема, на початку 2014 року корпорація Google придбала вісім компаній, які займаються інтелектуальною робототехнікою. В кінці 2018 р. компанія Google оголосила про впровадження платформи Google Cloud Robotics у 2019 році, в якій поєднуються хмарні технології, робототехніка та технології штучного інтелекту. Основним призначенням веб-платфрорми $є$ створення відкритої екосистеми рішень для автоматизації з використанням пов'язаних з хмарою роботів, що працюють у спільному середовищі [6];

- зростання попиту на спеціалістів робототехнічної галузі в цілому, оскільки вже зараз існує нагальна потреба у фахівцях для розробки, конструювання та програмування роботів [4];

- підвищення популярності робототехніки як освітнього тренду в Україні та світі, в т.ч. як наслідок у зв'язку з інтенсивним розвитком даної галузі та високою затребуваністю відповідних фрахівців [3].

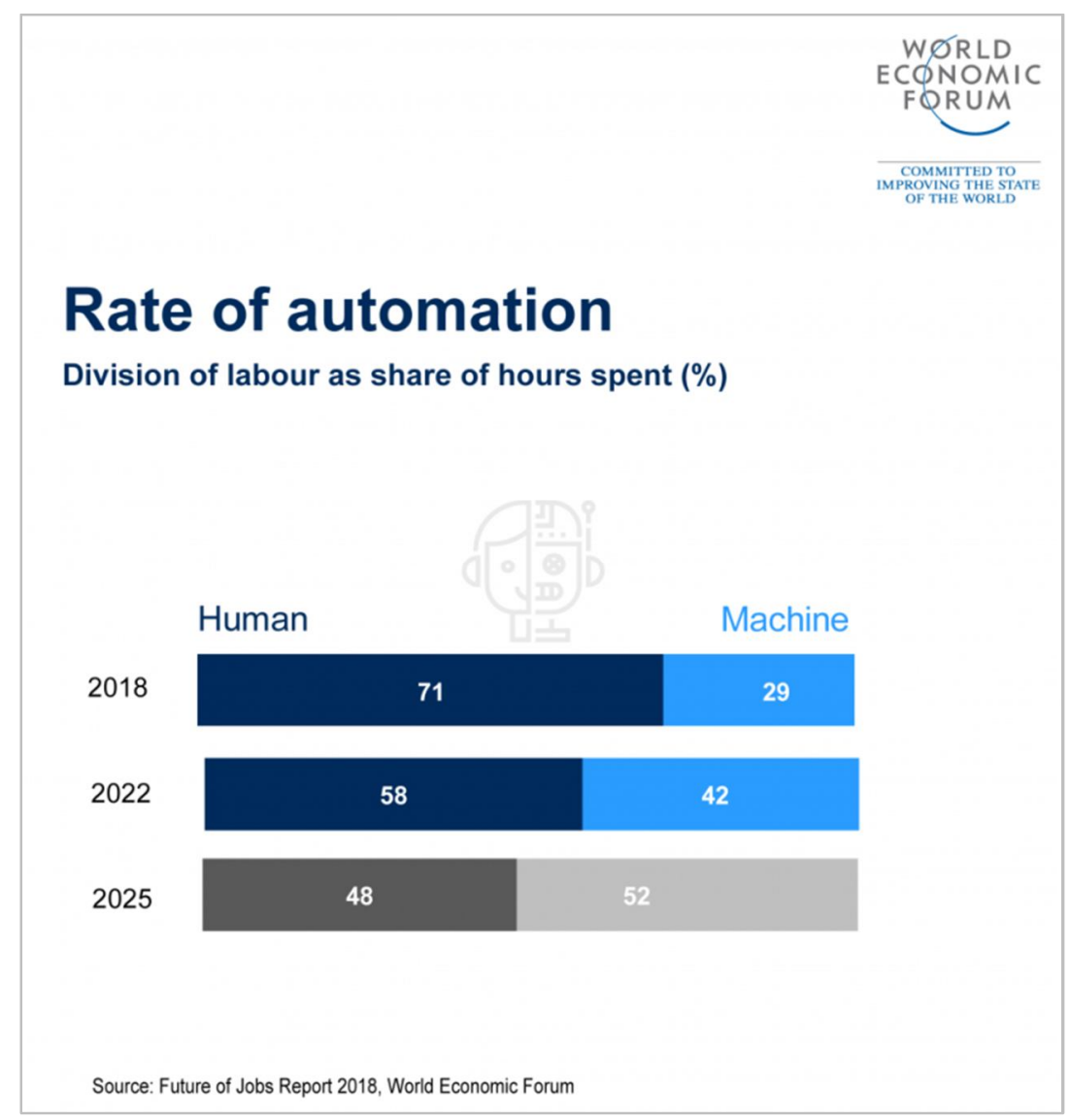

Рис. 1. Динаміка зміни співвідношення у розподілі праці "людина-робот" до 2025 р. у зв'язку 3 прискоренням швидкості автоматизації виробництва (за даними [4]) 
Таким чином, із зазначеного можна зробити висновки про стрімкий розвиток робототехніки, що, у свою чергу, спричиняє потребу у підготовці відповідних кваліфікованих фахівців.

Мета написання роботи: охарактеризувати освітню робототехніку як потужний інструмент STEMосвіти; проаналізувати міжпредметні зв'язки освітньої робототехніки, зокрема із STEM-предметами; визначити можливі напрями впровадження освітньої робототехніки в навчальний процес українських шкіл.

\section{II Матеріал і методи дослідження}

У процесі даного дослідження використовувалися такі методи:

- аналіз стану розвитку освітньої робототехніки в Україні:

- системний аналіз наукових і методичних джерел з питань використання робототехніки в освіті та у процесі навчання STEM-предметів;

- спостереження процесу навчання робототехніки;

- порівняння навчальних програм з освітньої робототехніки різних закладів освіти (шкільної та позашкільноі);

- участь у тематичних заходах, присвячених робототехніці (зустрічі з фахівцями, практикуючими вчителями, викладачами, менторами; участь у семінарах, майстер-класах тощо);

- аналіз та узагальнення даних, зібраних на тематичних заходах, присвячених робототехніці;

- опитування українських освітян та науковців з метою визначення популярності робототехніки як освітнього тренду; аналіз отриманих результатів;

- пошук релевантних даних для визначення умов впровадження освітньої робототехніки в навчальний процес закладів середньої освіти;

- узагальнення зазначених даних та власного досвіду авторів у галузі робототехніки взагалі та освітньої робототехніки зокрема.

В опитуванні стосовно визначення популярності робототехніки як освітнього тренду в Україні взяли участь 254 українських освітян та науковців (вчителів, викладачів університетів та коледжів, дослідників, аспірантів галузі освіти, майбутніх учителів та ін.) з різних шкіл та університетів України.

\section{III Результати}

\section{1. Популярність робототехніки як освітнього тренду}

Робототехніка $є$ популярним та ефективним методом для вивчення важливих галузей науки, конструювання й базується на активному використанні сучасних технологій у виробництві, IКТ та високому інтелектуальному рівні фахівців, які будуть працювати в умовах інноваційної економіки.

Коли мова йде про робототехніку в контексті її використання в навчальному процесі, то говорять про новий напрям в освіті - "освітню робототехніку" ("educational robotics").

Освітня робототехніка (educational robotics) - міжпредметний напрям навчання учнів, у процесі якого інтегруються знання зі STEM-предметів (фізики, технологій, математики), кібернетики, мехатроніки та інформатики [7; С. 182].

Для підтвердження популярності робототехніки як освітнього тренду в Україні, актуальності та важливості її навчання в українських школах авторами в 2019 р. було проведено дослідження серед українських освітян та науковців із шкіл та університетів усіх областей України, в якому взяли участь 254 чол. (вчителів, викладачів університетів та коледжів, дослідників, аспірантів галузі освіти, майбутніх учителів та ін.). Детальніше ознайомитись з результатами зазначеного дослідження можна в роботі [1].

Наведемо окремі його результати, що показують популярність освітньої робототехніки в Україні, актуальність та важливість її навчання в українських школах (рис. 2-6):

- Чи погоджуєтесь Ви з тим, що робототехніка є сучасним освітнім трендом (рис. 2)?

- Чи вважаєте Ви, що робототехніку необхідно впроваджувати в шкільну освіту (рис. 3)?

- В які школи, на Вашу думку, потрібно впроваджувати робототехніку (рис. 4)?

- Яким чином, на Вашу думку, можливо впроваджувати робототехніку в школи України (рис. 5)?

- Чи потрібно, на Вашу думку, робототехніку виділити в окрему предметну галузь, наприклад, "Освітня робототехніка" (рис. 6)? 


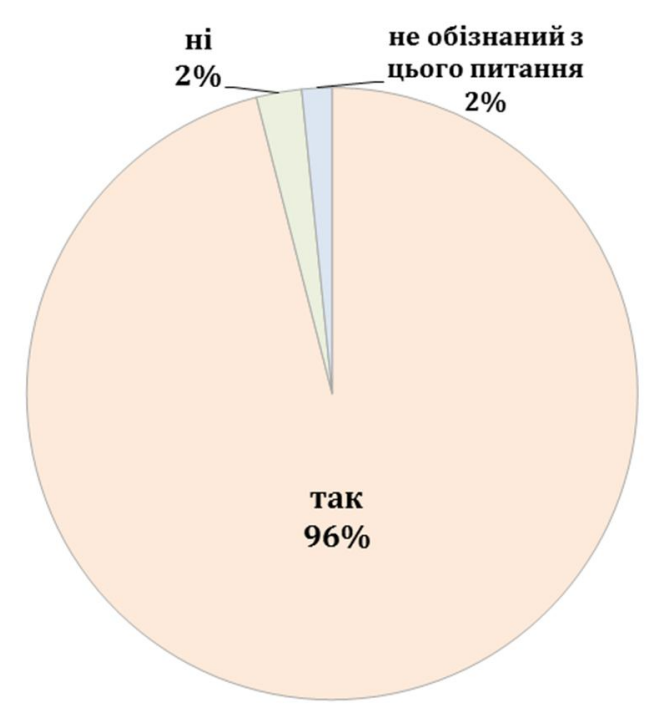

Рис. 2. Розподіл відповідей респондентів

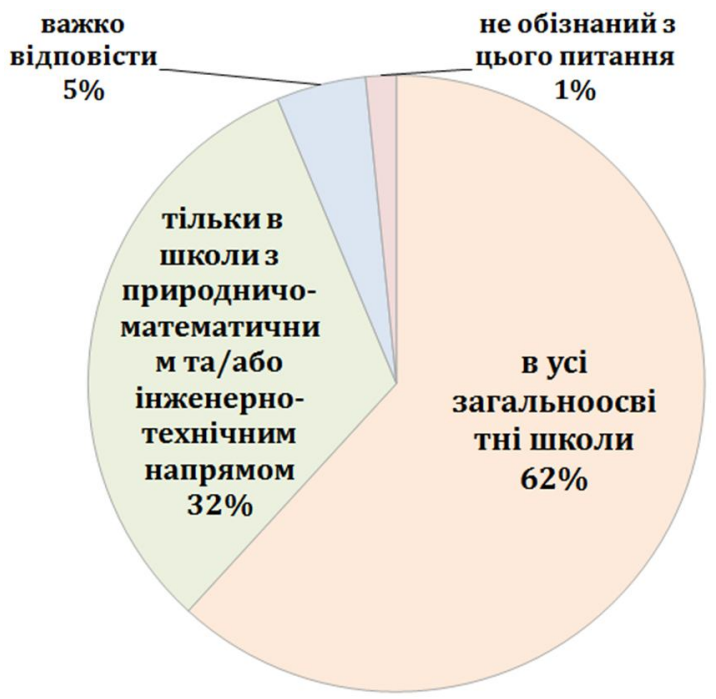

Рис. 4. Розподіл відповідей респондентів

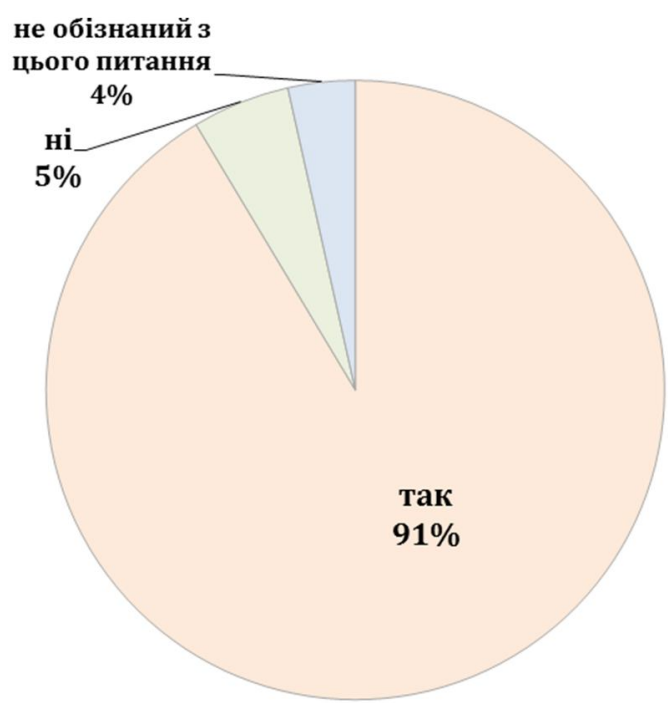

Рис. 3. Розподіл відповідей респондентів

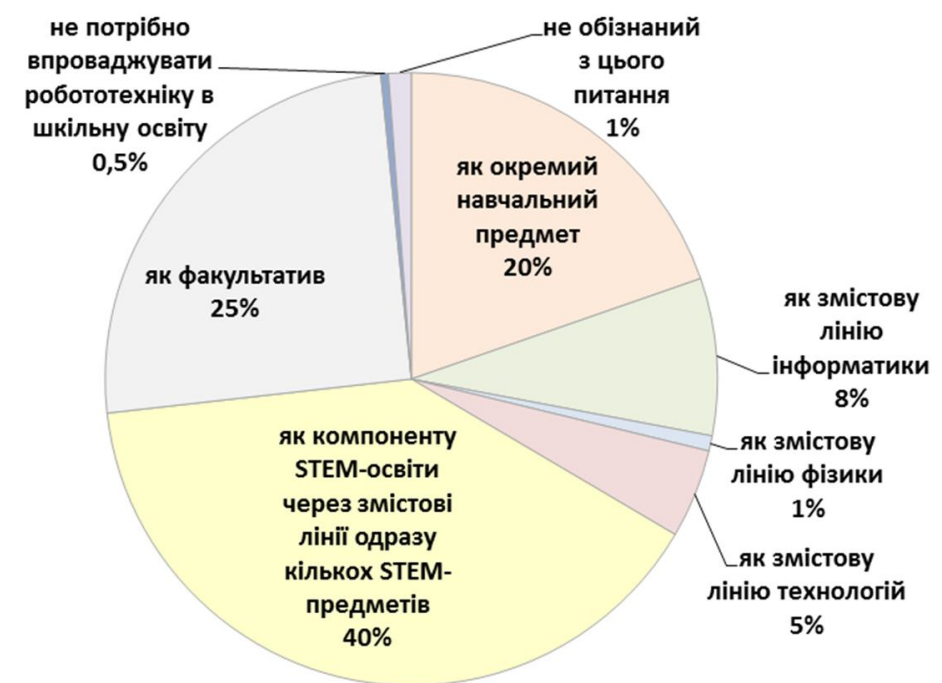

Рис. 5. Розподіл відповідей респондентів

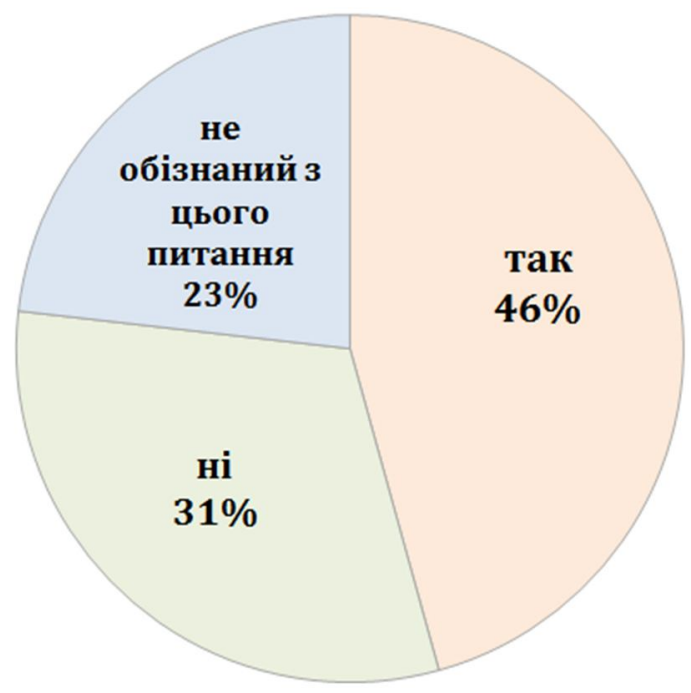

Рис. 6. Розподіл відповідей респондентів 
Таким чином, проведене дослідження показує збільшення популярності робототехніки як освітнього тренду в Україні, а також підтверджує актуальність і своєчасність її впровадження в українську школу.

\section{2. Освітня робототехніка як напрям STEM-освіти та їі міжпредметні зв'язки}

Як було зазначено раніше, стрімкий розвиток IT-галузі, робототехніки, нанотехнологій спричиняє потребу у підготовці відповідних кваліфікованих фахівців. Для реалізації цього необхідне якісне навчання учнів STEM-предметів - математики, фрізики, технологій, інженерії, інформатики, IKT, програмування тощо.

STEM-освіma (від англ. - Science, Technology, Engineering, Mathematics - наука, технологія, інженерія (технічна творчість), математика) - це напрям в освіті, в умовах використання якого в навчальних програмах посилюється природничо-науковий компонент із застосуванням інноваційних технологій (рис. 7).

STEM-освіта є одним з інструментів підготовки фрахівців майбутнього, здатних креативно мислити та створювати інновації. Освіта в галузі STEM $€$ основою для підготовки фрахівців у галузі високих технологій. У розвинутих країнах світу STEM-освіту підтримують на найвищому державному рівні, тому сьогодні багато країн, таких як Австралія, Великобританія, Данія, Ізраїль, Китай, Корея, Сінгапур, США, Японія, розвивають державні програми у даній галузі [7].

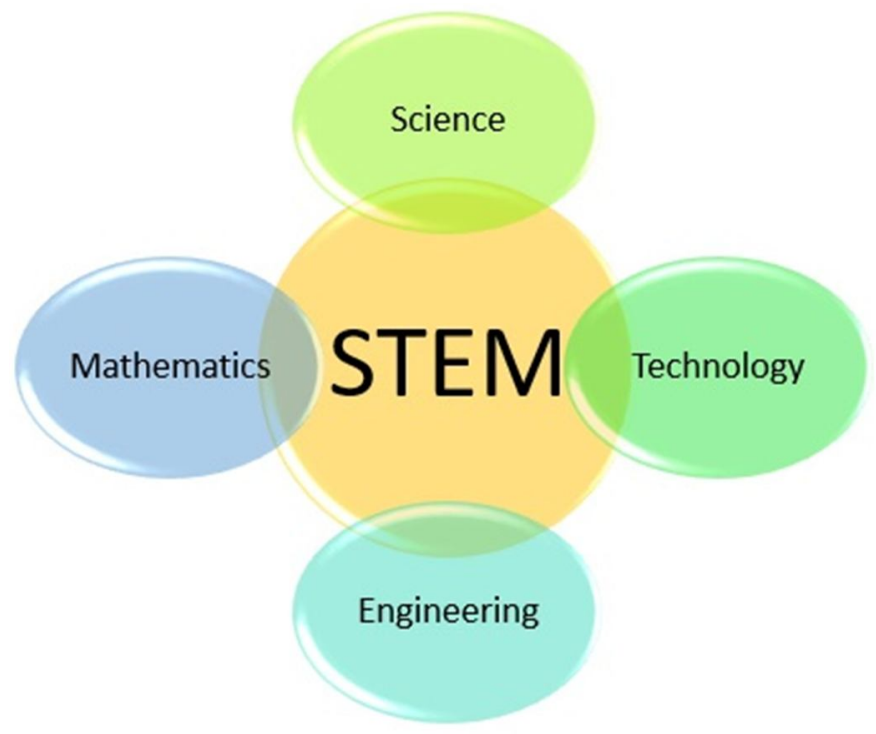

Рис. 7. Складові STEM-освіти

Орієнтовні оцінки на ринку професій у США показують, що в період з 2017 р. по 2027 р. загальна кількість робочих місць у STEM-професіях зросте на 13\% порівняно з 9\% робочих місць, що не належать до STEM. Особливо ці зміни стосуються галузі комп'ютерних наук, інженерії, машинобудування та виробництва (рис. 8). На сьогодні STEM-професії складають 7\% усіх від усіх робочих місць США, а попит на фрахівців у галузі STEM постійно зростає [8].

Роботодавці багатьох країн Європи також мають проблеми з найманням кваліфікованих фахівців у галузі STEM, особливо фахівців з IKT. Останні дані PISA показують, що більшість підлітків 15-річного віку в Європі функціонально неграмотні з математики та природничих наук [9].

На жаль, в Україні такожє серйозні проблеми у даній галузі. Індикатор інновацій в Україні, а також рівень технологічної забезпеченості робочої сили є одним з найнижчих порівняно з рештою показників конкурентоспроможності нашої країни. Відповідно до Всесвітнього звіту про конкурентоспроможність за 2018 р. Україна посіла 83 місце із 140 країн [10]. А за показником інноваційної доступності Україна він займає 58 місце [11]. Такі показники є характерними для країн пострадянського простору. 
STEM jobs will grow
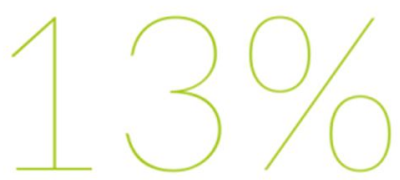

\ $14 \%$ Computing

$\Delta$ 7\% Engineering

A $12 \%$ Advanced Manufacturing
All other jobs will grow

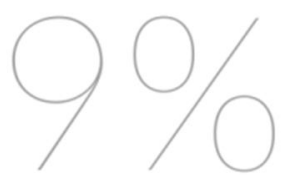

Рис. 8. Прогнозоване зростання STEM-професій з 2017 р. по 2027 р. у США

У той же час, інновації, модернізація освіта та підготовка кадрів є ключовими пріоритетами стратегіï "Європа 2020" ("Europe 2020 strategy" - Joint Report of the Council and the Commission on the implementation of the strategic framework for European cooperation in education and training (ET 2020), Official Journal C 417/25 of 15.12.2015) [12]. Нарощування потенціалу та розвиток інноваційних шляхів зв'язку науки та суспільства $є$ пріоритетом не лише для багатьох країн $€ С$, а й для України. Школи перебувають на передовому плані в подоланні цього розриву між уміннями майбутніх спеціалістів та високим попитом на кваліфікованих фахівців STEM-професій. Такі навички та мотивацію до навчання STEM-предметів потрібно розвивати у дітей з раннього віку.

До основних STEM-предметів (математики, фрізики, технологій тощо) важливо також залучати галузі, які швидко розвиваються. До таких галузей зокрема належать робототехніка та 3D-технології.

Робототехніка та 3D-технології - це потужний інструмент для навчання, який підходить для будьякого віку (від учнів початкових класів до студентів та викладачів університету). Використання освітньої робототехніки та 3D-технологій надає можливість на ранньому етапі виявити технічні нахили учнів та розвинути їх у цьому напрямку, а також сприяти формуванню в них STEM-компетентностей в цілому.

Таким чином, освітня робототехніка та 3D-технології $€$ перспективними напрямами сучасної STEM-освіти (рис. 9).

Зокрема, навчання освітньої робототехніки надає можливість учням і студентам вирішувати реальні життєві проблеми, які потребують знань STEM-предметів, зокрема [7]:

- $\quad$ математики (просторові поняття, геометрія - для розуміння способів руху роботів);

- різики (електроніка, принципи роботи датчиків, що є основою роботів);

- технологій та дизайну (дизайн пристроїв, частин роботів, їх конструювання),

- $\quad$ інфрорматики, IKT (програмування робототехнічних систем).

Одним із шляхів підвищення конкуретноспроможності нашої країни, зокрема в IT-галузі, $€$ введення до шкільної програми предметів, пов'язаних з сучасними IKT, а саме освітньої робототехніки та 3D технологій. Ці міркування також підтверджують своєчасність та актуальність виділення робототехніки в окрему предметну галузь та введення у майбутньому в навчальний процес українських шкіл окремого навчального предмету - шкільного курсу робототехніки. 


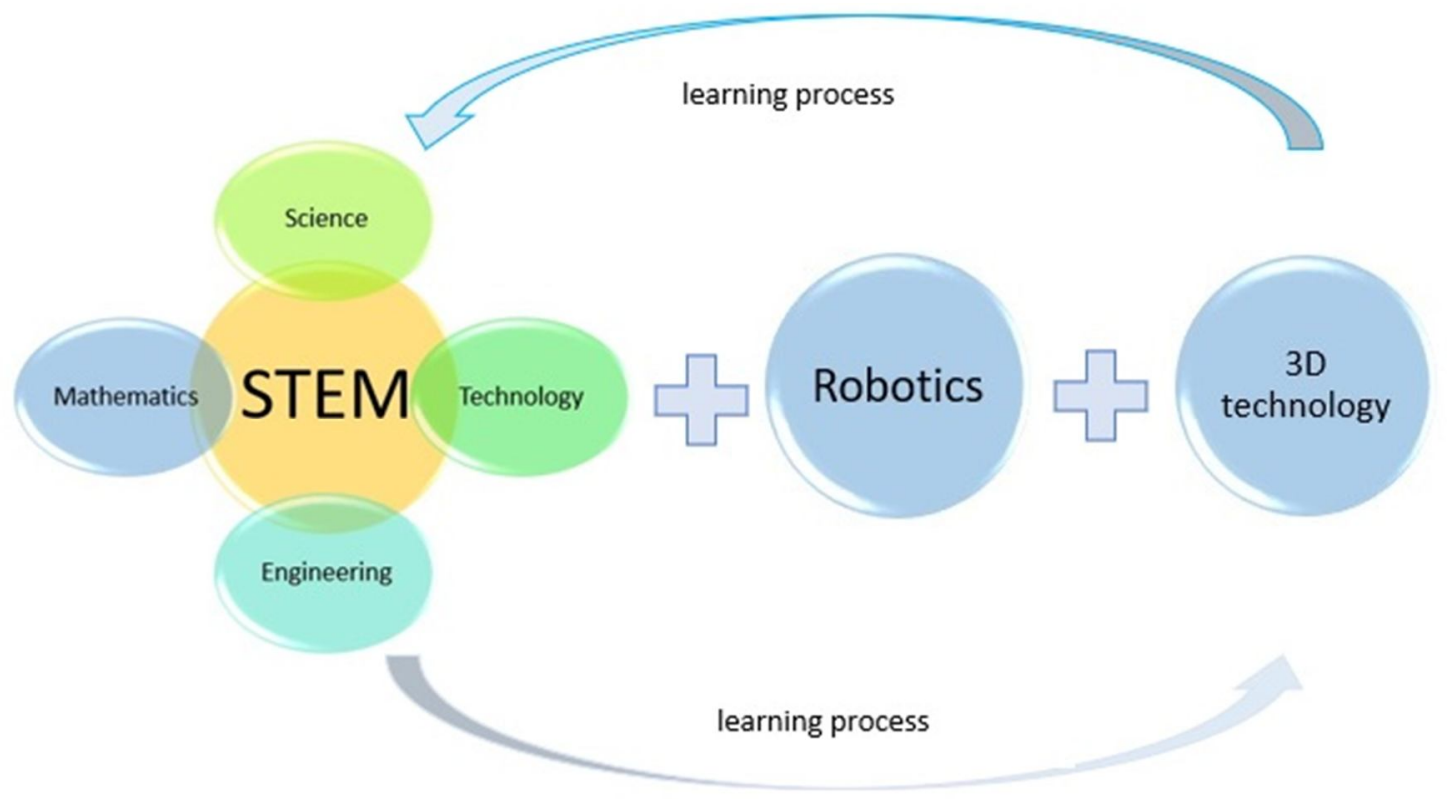

Рис. 9. Робототехніка та 3D технології як перспективні напрями STEM-освіти

Аналіз міжпредметних зв'язків освітньої робототехніки показав, що вона є міждисциплінарним предметом, який знаходиться на стику багатьох природничо-наукових та технічних напрямів (рис. 10):

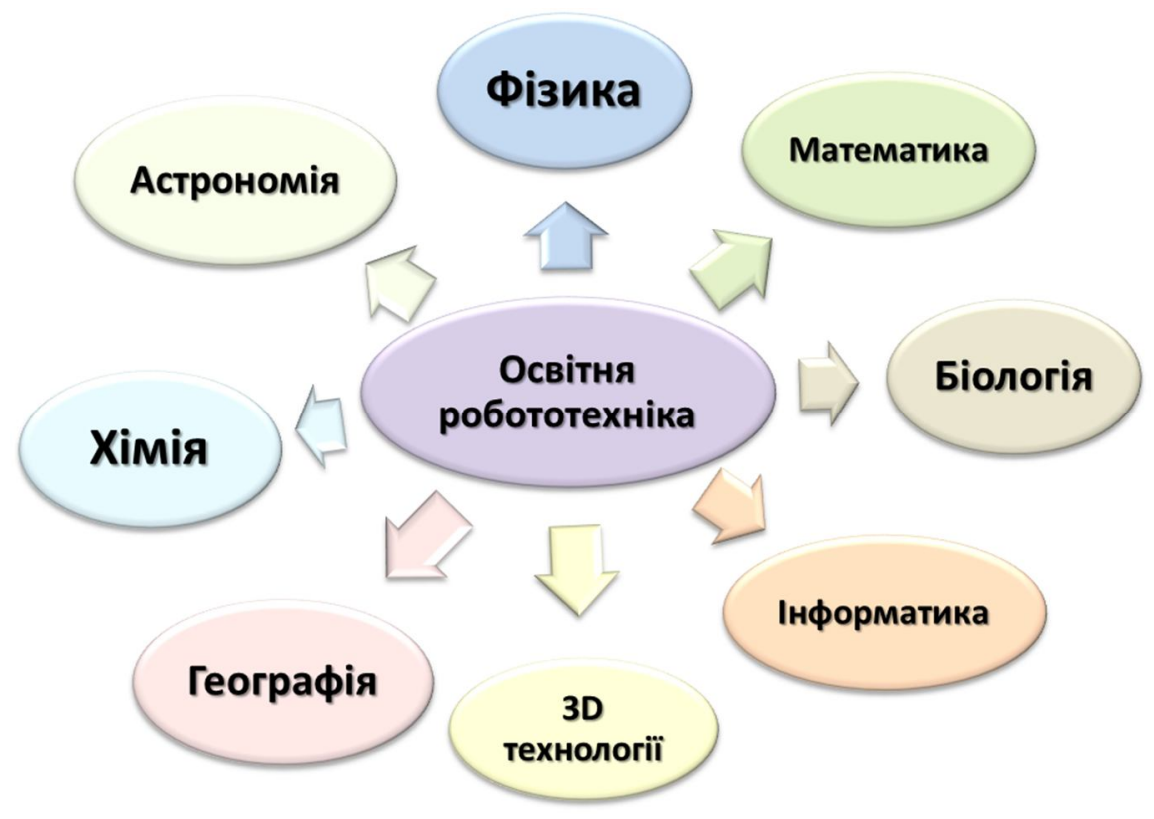

Рис. 10. Міжпредметні зв'язки освітньої робототехніки

Детальніше охарактеризуємо міжпредметні зв'язки освітньої робототехніки.

Інформатика: завдяки інтуїтивному зрозумілому програмному забезпеченню, що використовується у процесі навчання освітньої робототехніки, учні на доступному для них рівні засвоюють достатньо складні поняття програмування, такі як: змінні та константи, масиви, типи даних, логічні дані, математичні операції, інтервали, цикли, розгалуження, перемикачі, випадкові значення тощо. Це є своєрідною пропедевтикою для навчання учнів у майбутньому консольного програмування.

Математика: вивчення або повторення певних математичних понять, операцій. Наприклад, таких як: коло, круг, радіус, діаметр, пряма, кут, поворот тощо, а також виконання різноманітних розрахунків. 
Фізика: за допомогою побудови різноманітних конструкцій учні мають можливість на доступному для них рівні вивчати прості механізми, проводити різноманітні фізичні експерименти. Сюди також належить вивчення законів фрізики, різноманітних фізичних явищ (температури, прискорення, відновлювальних джерел енергії тощо).

Хімія: вивчення температурного перебігу екзотермічних та ендотермічних хімічних реакцій тощо.

Географія: створення роботів, за допомогою яких можна проводити роботу з картами, вивчати масштаб, протяжність географічних об'єктів: річок, гірських хребтів, державних кордонів, автомобільних шляхів тощо; визначати відстані між об'єктами та протяжність материків і держав (наприклад, з півночі на південь, із заходу на схід) тощо.

Біологія: дослідження явищ транспірації, зміни температури в приміщенні протягом уроку, температури класної кімнати (з рослинами і без); вимірювання вологості ґрунту за допомогою відповідних датчиків тощо.

3D-технології: робота в середовищах для 3D-моделювання роботів, 3D-моделювання та 3Dдрукування каркасних деталей роботів; розвиток навичок моделювання 3D-об'єктів, розвиток образного та просторового уявлення, формування та розвиток міждисциплінарних компетентностей, оскільки для ефективного використання 3D-технологій також необхідні знання з математики, фрізики, моделювання та програмування.

Астрономія: вивчення принципів функціонування роботів-телескопів; створення моделей роботів для дослідження далеких планет, наприклад, моделі робота-марсоходу, що дозволяє продемонструвати деякі функції реального марсоходу. За допомогою таких моделей можна відтворити процес буріння порід, визначити принцип стеження марсоходу за пересуванням джерел світла, від якого відбувається заряджання сонячних батарей і т.п.

Зважаючи на зазначене, заняття 3 освітньої робототехніки забезпечують реалізацію міжпредметних зв'язків із STEM-предметами, а також практичне використання знань точних наук (рис. 11):

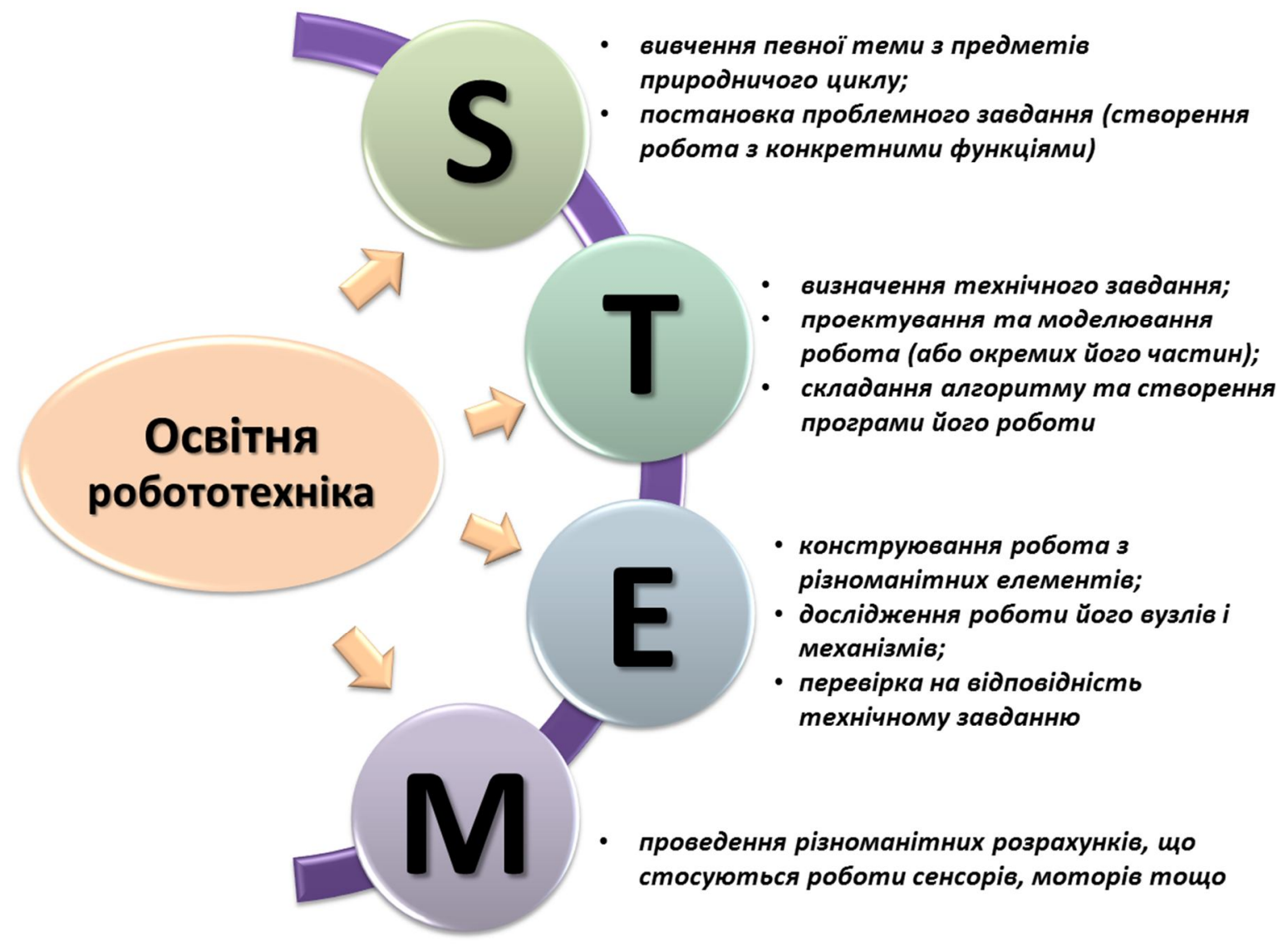

Рис. 11. Реалізація міжпредметних зв'язків освітньої робототехніки із STЕМ-предметами 
Крім того, такі заняття повинні включати в себе наступні компоненти:

1. Ідею створення конкретного робота та відповідне технічне завдання.

2. Моделювання робота.

3. Конструювання робота.

4. Складання алгоритму роботи та програмування робота відповідно до технічного завдання.

5. Тестування робота.

Наведемо приклад практичного використання знань STEM-nредметів у процесі виконання інтегрованого проекту освітньої робототехніки з географією.

Постановка задачі: на уроках географії в різних класах часто доводиться працювати з кривими лініями на картах: робота з планами, визначення протяжності з півночі на південь (із заходу на схід) материків, держав, берегових ліній материків, кордонів держав, довжин річок, транспортних магістралей тощо. Для таких розрахунків учні повинні знати поняття "масштаб" і вміти ним користуватись. Зазначимо, що для вимірювання кривих ліній використовується спеціальний прилад - курвіметр.

Meта створення проекту: розробити універсальну модель робота-курвіметра, який би допоміг вимірювати криволінійні об'єкти для вирішення картографічних задач.

Для реалізації даного проекту за основу було взято робот LEGO Mindstorms EV3 Education.

Покажемо основні напрями використання знань з кожним STEM-предметом у процесі роботи над даним проектом:

S (science) - перед початком роботи над проектом потрібно повторити/вивчити поняття "масштаб". На даному етапі відбувається уточнення проблемного завдання (створення моделі роботакурвіметра). Прилад має бути достатньо точним і виводити на дисплей значення довжини криволінійного об'єкта у кілометрах. Обов'язково повинен бути передбачений вибір масштабу в залежності від карти, яка буде використовуватись.

T (technology) - на цьому етапі можна зробити ескіз моделі робота або можна змоделювати ії за допомогою відповідного програмного забезпечення (програм для 3D-дизайну): LDD, MLCad, LDCad тощо.

Після того, як робот буде сконструйований і проведені усі відповідні розрахунки, необхідно скласти алгоритм роботи і написати програму його роботи.

E (engineering) - протягом цього етапу відбувається конструювання робота відповідно до вимог і 3D-моделі, що була розроблена на попередньому етапі.

M (mathematics) - для написання програми необхідні розрахунки, а саме для цього потрібно розрахувати довжину кола колеса (використовуються діаметр і число $\pi$ ), визначити градусну міру кута повороту вихідного валу мотора за 1 мм пройденого шляху, визначити масштаб карти та провести розрахунки для отримання остаточного значення.

Після тестування роботи розробленої моделі робота-курвіметра часто виникає потреба повернутися до одного з етапів і відкоригувати модель, розрахунки або/та програму.

Крім даного прикладу автором у процесі власного практичного досвіду навчання освітньої робототехніки було реалізовано інтегровані проекти освітньої робототехніки з біологією, хімією, фізикою, основами здоров'я та ін.

Приклади подібних проектів яскраво демонструють практичне застосування знань точних наук у процесі навчання освітньої робототехніки та показують важливість її впровадження в українські школи.

\section{3. Напрями впровадження освітньої робототехніки в заклади освіти}

Аналіз останніх досліджень та публікацій у галузі освітньої робототехніки показав, що нині науковцями та освітянами України активно ведуться пошуки шляхів впровадження та використання робототехніки в навчальному процесі закладів освіти (Н.В. Морзе, Р.С. Белзецький, Д.В.Боровик, А.Д. Василюк, М.А. Гладун, М.А. Гезалова, С.М. Дзюба, О.В. Задорожна, І.В. Кіт, О.Г. Кіт, П.О. Клименко, Ю.Г. Ковальов, Д.І. Кожем'яка, О.М. Кривонос Т.І. Лисенко, В.Ю. Луценко, А.І. Лучковський, О.С. Мартинюк, Г.В. Мічуріна, К.С. Ніфантьєв, В.М. Ніколайчук, І.П. Оніщук, С.С. Пахачук, В.А. Соколов, М.А. Умрик, С.А. Хачатрян, Б.О. Шевель та ін.). 
Однак, аналіз їх досвіду та власний досвід показують, що в Україні питанням розвитку робототехніки в рамках освітнього процесу приділяється недостатньо уваги [3; С. 196, С. 201]. Зокрема навчання освітньої робототехніки в закладах освіти в цілому відбувається епізодично, що також підтверджується результатами дослідження [1]:

- в школах у процесі навчання інформатики, IKT, технологій, фрізики (як модулів або/та окремих тем);

- на фракультативах та гуртках у закладах середньої загальної освіти в позаурочний час (в т.ч. у процесі підготовки учнів до участі в роботі Малої академії наук (МАН); фестивалях, конкурсах, змаганнях з робототехніки на українському та міжнародному рівнях; для розвитку наукового-технічної творчості школярів тощо);

- у закладах позашкільної освіти (як державних, так і комерційних).

Це говорить про відсутність системного підходу до навчання освітньої робототехніки в українських школах, що пов'язано з тим, що за державним стандартом освіти на сьогодні не існує окремої освітньої галузі "Робототехніка".

Однак, аналіз світових тенденцій розвитку робототехніки як прикладної галузі; аналіз стану розвитку робототехніки як освітнього тренду; аналіз даних, зібраних на тематичних заходах, присвячених робототехніці; системний аналіз наукових, методичних та Інтернет-джерел з проблеми дослідження, а також результати проведеного дослідження серед українських науковців і освітян (рис. 3-6) свідчать про те, що на сьогодні виникає необхідність у визначенні шляхів впровадження освітньої робототехніки у навчальний процес закладів освіти.

Зокрема автори дослідження вважають, що назріла нагальна потреба у виділенні робототехніки в окрему предметну галузь "Освітня робототехніка", після чого наступним логічним кроком є введення в українські школи окремого навчального предмету - шкільного курсу робототехніки.

На теперішній час для вирішення зазначеної проблеми головним питанням серед науковців та освітян, які займаються впровадженням освітньої робототехніки у навчальний процес, є питання:

\section{"Якою повинна бути шкільна робототехніка?"}

Для цього вирішення цього питання авторами також було проаналізовано наступні існуючі програми з робототехніки в закладах шкільної та позашкільної освіти: [14-26].

Таким чином, на основі проведеного аналізу існуючих програм навчання робототехніки в закладах шкільної та позашкільної освіти, узагальнення зазначених даних, власних попередніх досліджень (20172019 рр.) та власного досвіду навчання освітньої робототехніки (з 2006 р.) автори умовно виділяють 5 основних напрямів впровадження освітньої робототехніки у навчальний процес закладів шкільної освіти [13], які в подальшому можуть бути визначені як модулі майбутнього шкільного курсу робототехніки (табл. 1).

Табл. 1. Напрями впровадження (модулі) освітньої робототехніки в заклади освіти

\begin{tabular}{|l|l|c|}
\hline $\begin{array}{c}\text { № } \\
\text { пор. }\end{array}$ & Назва напряму (змістової лінії) & $\begin{array}{c}\text { Клас / вік, 3 якого пропонується } \\
\text { впроваджувати даний напрям (модуль) у } \\
\text { закладах освіти }\end{array}$ \\
\hline 1. & $\begin{array}{l}\text { Робототехніка для дошкільнят } \\
\text { (пропедевтичний курс) }\end{array}$ & 3-6 років \\
\hline 2. & Класична робототехніка & початкова, середня школа \\
\hline 3. & Базово-модельна робототехніка & початкова, середня школа \\
\hline 4. & Мейкерство в робототехніці & середня школа \\
\hline 5. & Проектна робототехніка & старші класи \\
\hline
\end{tabular}

Коротко охарактеризуємо кожний напрям окремо.

Робототехніка для дошкільнят (First robotics).

Цей напрям фрактично є пропедевтикою навчання освітньої робототехніки в закладах шкільної освіти. 
На думку багатьох практиків та дослідників методичних питань навчання освітньої робототехніки, починати її впровадження у навчальний процес варто ще з дитячого садка. Освітні рішення для цього $€$ в достатній кількості. Так, наприклад, концепт First Bot (перший робот) повністю розкриває особливості навчання робототехніки для дітей цього віку. На цьому рівні варто вперше ознайомити дітей з роботами. Причому, це можна робити, починаючи вже з 3-х років. Також, слід відмітити, що на даному етапі конструювання роботів або відсутнє, або зведене до мінімуму, проте відбувається інтенсивний розвиток логічного та алгоритмічного мислення. Такі заняття можуть допомогти дітям дошкільного віку отримати початкові уявлення про такі речі, як послідовності, цикли, алгоритми; засвоїти ази програмування. Цікавою рисою робототехнічних рішень для дошкільнят $€$ відсутність роботи 3 комп'ютерами, ноутбуками та іншими ґаджетами, що є дуже позитивним моментом, оскільки дозволяє уникнути дітям звикання до роботи з такими пристроями.

У молодшій школі зазвичай робототехніка розділяється на два напрями: "Класична робототехніка" та "Базово-модельна робототехніка".

\section{Класична робототехніка (Classic robotics).}

В основі цього напряму лежить застосування готових робототехнічних наборів, з яких можна збирати велику кількість моделей. Для пояснення головної мети впровадження даного напрямку наведемо одне з означень робототехніки.

Робототехніка - це прикладна наука, в якій вивчається проектування, розробка, конструювання, експлуатація та використання роботів. Причому зазначені процеси включають в себе: постановку задачі, яку можна виконати за допомогою робота; моделювання, конструювання, програмування, тестування та вдосконалення робота.

Зважаючи на зазначене, класична робототехніка включає в себе такі складові, як:

- ідею створення конкретного робота та відповідне технічне завдання;

- моделювання робота (на перших кроках відбувається детальний огляд майбутньої моделі, а з часом учні можуть самостійно робити ескізи та створювати їх 3D-моделі);

- конструювання робота, ознайомлення учнів з основами побудови різноманітних конструкцій, збирання простих і складних механізмів та механічних передач;

- ознайомлення учнів з основами мікроелектроніки (вивчення принципів роботи електронних компонентів робота: моторів, сенсорів, робототехнічних плат тощо);

- складання алгоритму роботи та програмування робота відповідно до технічного завдання;

- тестування робота (вдосконалення конструкції та програми, якщо в цьому є необхідність).

Розглянуті складові $€$ дуже важливими на початку формування в учнів знань з робототехніки, набуття ними відповідних навичок, а також для усвідомлення школярами того, що робот - це складна електромеханічна система.

\section{Базово-модельна робототехніка (Base-model robotics).}

У даному напрямі передбачено використання однієї або кількох базових моделей робота протягом всього курсу навчання. При цьому учні отримують нові знання та навички з основ програмування та мікроелектроніки. Також, зважаючи на рівень підготовки школярів, сюди можна віднести 3D-моделювання та вдосконалення роботів різноманітними підручними матеріалами. У даному напрямі можна також поглибити навички візуального програмування (за допомогою блоків), адже таке програмування роботів виступає потужним інструментом для простого і зрозумілого пояснення достатньо складних понять програмування, що необхідно на початку формування відповідних умінь i навичок з робототехніки. Крім того, школярі можуть швидко перевірити результати своєї діяльності (наприклад, результати дії програми, роботи робота, відлагодити їх за потреби).

За даним напрямом передбачено також, щоб учні на уроках самостійно створювали роботів, програмували їх на виконання певних дій. Таким чином, відбувається усвідомлення зв'язку між створеною програмою і діями робота. Така структура дає можливість крок за кроком навчати школярів не тільки робототехніки, а й основ програмування, щороку ускладнюючи завдання та поглиблюючи їх знання.

Оскільки протягом навчання за даним напрямом, в основному, використовується тільки одна модель, необхідно побудувати курс так, щоб зберегти мотивацію учнів до навчання. 
Робототехніку середньої та старшої школи, окрім попередніх напрямів, доповнюють "Мейкерство в робототехніці" та "Проектна робототехніка".

\section{Мейкерство в робототехніці (Open-source robotics).}

Метою навчання робототехніки за даним напрямом $€$ ознайомлення учнів з електронними компонентами та основами створення каркасів і механічних вузлів. В процесі навчання школярі знайомляться з різноманітними платами, вчаться їх програмувати та працювати з інтегрованими та периферійними пристроями (мотори, сенсори тощо). В цей курс важливо також включити основи мікроелектроніки та паяння. Даний напрям є одним з базових, оскільки охоплює такі теми:

- основи електрики та мікроелектроніки (робота з мультиметром, прокладання електропроводки тощо), робота з аналоговими та цисрровими сигналами, протоколи, основи програмування плат (деякі 3 плат можна програмувати на 3-4 мовах програмування) тощо.

- 3D-технології (3D-моделювання і 3D-друкування);

- робота з каркасними матеріалами (металами, деревом, акрилом, оргсклом, пластиком, фанерою, картоном тощо). При роботі з ними доцільно ознайомити учнів з основами свердління та монтажно-фріксаційними елементами (болти, гайки, шайби, саморізи, стяжки, клеї, термоклеї тощо). Ці знання та уміння є підґрунтям для т.з. мейкерства - DIY (Do It Yourself - "зроби це сам"), loT (Internet of Things - Інтернету речей), Smart House ("розумного будинку") тощо.

\section{Проектна робототехніка (Project Robotics).}

В основі даного напряму лежить постійна робота з однією моделлю або проектом, що розробляється для підготовки до різноманітних змагань, олімпіад, фестивалів, наукових виставок тощо.

До напряму належить розробка робототехнічних стартапів; створення дронів, побутових, промислових роботів тощо. Цей напрям можна також охарактеризувати як "робототехніка для винахідників".

Варто відзначити, що до цього концепту належить створення роботів, де як каркаси використовуються не лише технічні деталі наборів, а й різноманітні каркасні матеріали, а також розроблені та надруковані на 3D-принтері власні деталі.

За напрямом передбачено постійна робота лише з однією моделлю з багаторазовим ії тестуванням та вдосконаленням. Цей напрям є логічним продовженням попереднього і орієнтований, в основному, на старші класи.

Окреслені нами напрями є авторським баченням того, за якими модулями можна впроваджувати освітню робототехніку в заклади шкільної освіти в Україні. На теперішній час питання стосовно того, якою повинна бути шкільна робототехніка, є дискусійним та відкритим. Автори даного дослідження будуть продовжувати працювати над розробкою концепції шкільного курсу робототехніки з урахування прогресивного закордонного та українського досвіду в даній галузі.

\section{IV Обговорення}

Проведене дослідження показує збільшення популярності робототехніки як освітнього тренду в Україні, а також підтверджує актуальність її впровадження в українську школу.

Однак, на теперішній час головним питанням серед науковців та освітян, які займаються впровадженням освітньої робототехніки у навчальний процес, $є$ питання: "Якою повинна бути шкільна робототехніка?"

В той же час, є багато інших питань, пов'язаних з впровадженням освітньої робототехніки в навчальний процес закладів шкільної освіти, які є також дискусійними. Наведемо найважливіші з них:

- який шлях впровадження освітньої робототехніки $є$ найефективнішим на теперішній час (чи буде освітня робототехніка виділена в окрему предметну галузь, про що свідчать вимоги сьогодення, чи буде введена в шкільний курс інформатики (фізики, технологій) як окремі модулі, змістові лінії тощо);

- чи потрібно впроваджувати освітню робототехніку в загальноосвітні школи, чи тільки в школи (класи) з природничо-математичним та/або інженерно-технічним профілем;

- відсутність концепції впровадження освітньої робототехніки в школи України;

- визначення мети, структури та змісту навчання освітньої робототехніки в школі;

- визначення віку (класу), з якого варто починати навчати дітей освітньої робототехніки; 
- вирішення питань матеріально-технічного, методичного, кадрового забезпечення навчального процесу освітньої робототехніки;

- відсутність кваліфікованих вчителів, які будуть навчати освітньої робототехніки. Для вирішення цього питання необхідне також оновлення змісту навчання університетської освіти відповідно до вимог сьогодення.

Однак, вищезазначене не знижує актуальності та своєчасності впровадження освітньої робототехніки в українські школи та необхідності підготовки майбутніх вчителів робототехніки. Вирішення наведених вище питань повинно відбуватись шляхом широкої відкритої дискусії серед науковців, освітян, представників IT-галузі та усіх обізнаних та зацікавлених фрахівців з даної проблематики.

\section{V Висновки}

Зважаючи на результати проведеного дослідження, можемо зробити висновки про високу соціальну затребуваність навчання освітньої робототехніки в українських школах як перспективного напряму STEM-освіти. Крім того:

- робототехніка $є$ популярним та ефективним методом для вивчення важливих галузей науки, конструювання й базується на активному використанні сучасних технологій у виробництві, ІКТ та високому інтелектуальному рівні фахівців, які будуть працювати в умовах інноваційної економіки;

- існує нагальна потреба у навчанні дітей освітньої робототехніки - для підготовки фахівців для майбутніх професій, пов'язаних з робототехнічною галуззю та для розвитку в учнів наукового мислення, технічної творчості, умінь знаходити рішення у непередбачуваних ситуаціях. До того ж, на заняттях 3 робототехніки учні практично застосують попередньо набуті знання з точних наук;

- цілком очевидною є необхідність у введенні освітньої робототехніки як обов'язкової складової шкільної програми.

Аналіз світових тенденцій розвитку робототехніки як прикладної галузі; аналіз стану розвитку робототехніки як освітнього тренду [1]; аналіз даних, зібраних на тематичних заходах, присвячених робототехніці; системний аналіз наукових, методичних та Інтернет-джерел з проблеми дослідження, а також результати проведеного дослідження серед українських науковців і освітян свідчать про те, що на сьогодні виникає нагальна потреба у визначенні шляхів та напрямів впровадження освітньої робототехніки у навчальний процес закладів освіти.

Зокрема автори дослідження вважають, що назріла нагальна потреба у виділенні робототехніки в окрему предметну галузь "Освітня робототехніка", після чого наступним логічним кроком є введення в українські школи окремого навчального предмету - шкільного курсу робототехніки. Крім того, авторами запропоновано 5 основних напрямів впровадження освітньої робототехніки у навчальний процес закладів шкільної освіти, які в подальшому можуть бути визначені як модулі майбутнього шкільного курсу робототехніки. Однак, це питання є відкритим на сьогодні, й автори дослідження готові до конструктивної дискусії стосовно питань розробки концепції шкільного курсу робототехніки. На вирішення вищезазначених питань і будуть спрямовані подальші дослідження авторів.

Такі кроки дозволять швидко і якісно підготувати дітей до сучасних умов інтенсивного розвитку інформаційних технологій, що, в свою чергу, надасть їм можливість в майбутньому стати конкурентоспроможними фахівцями IT-індустрії.

\section{Бібліографрічні посилання}

1. Струтинська О. В. Актуальність впровадження освітньої робототехніки в українську школу / Відкрите освітнє есередовище сучасного університету. 2019. 6. С. 115-134.

2. Global industrial robot sales doubled over the past five years - International Federation of Robotics. URL: https://ifr.org/ifrpress-releases/news/global-industrial-robot-sales-doubled-over-the-past-five-years (дата звернення 11.08.2019).

3. Струтинська О. В., Баранов С. С. Тенденції розвитку освітньої робототехніки в закладах позашкільної освіти / Фізикоматематична освіта. 2019. Випуск 1(19). С. 196-204.

4. The Future of Jobs Report 2018. URL: http://www3.weforum.org/ docs/WEF_Future_of_Jobs_ 2018.pdf ?fbclid=IwAR1dhE70_5g-sJBtXhct5L_mrCciaWzDv8aOWiHJJXvltfjEhlOMpfH1shs (дата звернення 11.08.2019). 
5. Hermann M., Pentek T. Otto B. Design Principles for Industrie 4.0 Scenarios: A Literature Review. Technische Universitat Dortmund, 2015. URL: http://www.iim.mb.tu-dortmund.de/cms/de/forschung/Arbeitsberichte/Design-Principles-for-Industrie4_0-Scenarios.pdf (дата звернення 11.08.2019).

6. Google Cloud Robotics Platform coming to developers in 2019. URL: https://www.therobotreport.com/google-cloud-roboticsplatform (дата звернення 11.08.2019).

7. Морзе Н. В., Струтинська О. В., Умрик М. А. Освітня робототехніка як перспективний напрям розвитку STEM-освіти / Відкрите освітнє е-середовище сучасного університету. 2018. 5. С. 178-187. URL: http://openedu.kubg.edu.ua/ journal/ index.php/openedu/article/view/175/233\#.XCVa1fmLTcs (дата звернення 11.08.2019)

8. Vital Signs | Education Commission of the States. URL: http://vitalsigns.ecs.org/state/united-states/demand (дата звернення 11.08.2019).

9. Why STEM subjects and democratic citizenship go together. Proceedings from the CESAER conference (19 October 2017). URL: $\quad$ https://ec.europa.eu/commission/commissioners/2014-2019/navracsics/announcements/why-stem-subjects-anddemocratic-citizenship-go-together_en Budapest (дата звернення 11.08.2019).

10. Global Competitiveness Report 2018 (Reports: World Economic Forum). Retrieved from: http://reports.weforum.org/globalcompetitiveness-report-2018/country-economy-profiles/\#economy=UKR (дата звернення 11.08.2019).

11. Morze N., Strutynska O., Umryk M. Implementation of robotics as a modern trend in STEM-education / International Journal of Research in E-learning. 2018. Vol. 4. Iss. 2(8). PP. 94-103.

12. Europe 2020. A European strategy for smart, sustainable and inclusive growth. URL: https:/lec.europa.eul eu2020/pdf/COMPLET\%20EN\%20BARROSO $\% 20 \% 20 \% 20007 \% 20$ - 20 Europe $\% 202020 \% 20-\% 20$ EN\%20version.pdf (дата звернення 11.08.2019).

13. RT - RoboTeacher -\#робозалежні:). URL: http://www.roboteacher.site (дата звернення 11.08.2019).

14. Боровик Д. В., Вовковінська Н. В., Войченко О. П. Програма курсу "Технічна творчість. Робототехніка 5-9 класи". Комп'ютер у школі та сім'і'. Київ, 2017, №3. С. $12-17$.

15. Василюк А. Д., Клименко П. О., Ніфантьєв К. С. Програма курсу за вибором "Робототехніка" для учнів 8-9 класів загальноосвітніх навчальних закладів. 2018. URL: http://ies.org.ua/wp-content/uploads/2018/08/GRIF_PROG_WEB.pdf (дата звернення 11.08.2019).

16. Гезалова М. А. Навчальна програма з позашкільної освіти науково-технічного напряму "Основи робототехніки та комп'ютерного моделювання". Запоріжжя, 2013. 12 c. URL: http://www.grani.in.ua/wp-content/ uploads/ 2018/10/ robotech_zrazok.doc (дата звернення 11.08.2019).

17. Дзюба С. М., Кіт І. В., Кіт О. Г., Мічуріна Г. В., Хачатрян С. А. Навчальна програма курсу за вибором з трудового навчання та технічної творчості для 5-9 класів загальноосвітніх навчальних закладів "Технологія керування робототехнічними системами". 2013.

18. Кіт І. В., Кіт О. Г. Програма курсу за вибором "Проектування робототехнічних систем" для вивчення у 7-9 класах. Листи IIT3О від 23.05.2013 № 14.1/12-Г-178. 2013. URL: https://drive.google.com/file/d/ OB7_wRGRJlavXV110 V1Zib2t0OWs/ view (дата звернення 11.08.2019).

19. Кожем'яка Д. І. Навчальна програма курсу за вибором "Основи робототехніки" для вивчення у 5-9 класах. Лист IM30 від 04.12.2015 № 2.1/12-Г-106. К.: Пролего, 2015. URL: http://leader.ciit.zp.ua/files/menu_r2/programs/p_lego.pdf вільний (дата звернення 11.08.2019).

20. Лисенко Т. І., Шевель Б. О. Програма курсу за вибором "Основи робототехніки" як варіативного модуля до навчальної програми "Технології. 10-11 класи". Лист ІІT3О від 19.02.2015 № 14.1/12-Г-50. URL: http://vynahidnyk.org/files/Doc2.doc (дата звернення 11.08.2019).

21. Луценко В. Ю. Використання засобів робототехніки при вивченні змістової лінії "Основи алгоритмізації та програмування": методичний посібник. Вінниця : ММК, 2015. 38 с.

22. Лучковський А. І., Соколов В. А. Технічна обдарованість старшокласників : методичні рекомендації. К. : Вид-во Інститут обдарованої дитини НАПН України, 2018. 253 с.

23. Лучковський А. І., Соколов В. А. Навчальна програма з позашкільної освіти дослідницько-експериментального напряму "Робототехніка", 2018. 77 c. URL: http://kyiv.man.gov.ua/ upload/2018/ \%D0\%9A\%D0\%B0\%D1 \%80\%D1 \%87\%D0\%B8\%D0\%BD\%D0\%B0/Robototexnika.pdf (дата звернення 11.08.2019).

24. Навчальна програма "Технології 10-11 класи" (рівень стандарту) 2017. 29 с. URL: https://mon.gov.ua/storage/app/media/zagalna\%20serednya/programy-10-11-klas/2018-2019/texnologiyi-ostatochnij-variant10.11.17.docx (дата звернення 11.08.2019).

25. Навчальні програми з позашкільної освіти. Науково-технічний напрям / за ред. Шкури Г. А., Ніколайко Н. Ю. К. : УДЦПО, 2018. Вип. 3. 117 с.

26. Пахачук С. С., Оніщук І. П. Збірник навчальних програм з позашкільної освіти дослідницько-експериментального напряму секції "Робототехніка" / упоряд. О.Ф. Бурбел]. Луцьк, 2016. 40 с.

\section{References}

1. Strutynska, O. (2019). Aktualjnistj vprovadzhennja osvitnjoji robototekhniky v ukrajinsjku shkolu. [Actuality of Implementation of Educational Robotics in Ukrainian School]. Open educational e-environment of modern University, 6, 115-134. (in Ukrainian)

2. Global industrial robot sales doubled over the past five years - International Federation of Robotics. Retrieved from: https://ifr.org/ifr-press-releases/news/global-industrial-robot-sales-doubled-over-the-past-five-years (accessed 11.08.2019). 
3. Strutynska, O., Baranov, S. (2019). Tendenciji rozvytku osvitnjoji robototekhniky v zakladakh pozashkiljnoji osvity. [Development Trends of the Educational Robotics in Out-of-school Institutions]. Physical and Mathematical Education, 1(19). 196-204. DOI 10.31110/2413-1571-2019-019-1-031 [in Ukrainian]

4. (2018). The Future of Jobs Report 2018. URL: http://www3.weforum.org/ docs/ WEF_Future_of_Jobs_ 2018.pdf ?fbclid=IwAR1dhE70_5g-sJBtXhct5L_mrCciaWzDv8a0WiHJJXvltfjEhlOMpfH1shs (accessed 11.08.2019).

5. Hermann, M., Pentek, T., Otto, B. (2015). Design Principles for Industrie 4.0 Scenarios: A Literature Review. Technische Universitat Dortmund. URL: http://www.iim.mb.tu-dortmund.de/cms/de/forschung/Arbeitsberichte/Design-Principles-forIndustrie-4_0-Scenarios.pdf, (accessed 11.08.2019).

6. Google Cloud Robotics Platform coming to developers in 2019. URL: https://www.therobotreport.com/google-cloud-roboticsplatform (accessed 11.08.2019).

7. Morze, N., Strutynska, O., Umryk, M. (2018). Osvitnja robototekhnika jak perspektyvnyj naprjam rozvytku STEM-osvity. [Educational Robotics as a prospective trend in STEM-education development]. Open educational e-environment of modern University, 5, 178-187. URL: http://openedu.kubg.edu.ua/ journal/index.php/ openedu/article/ view/175/233\#.XCVa1fmLTcs (accessed 11.08.2019). [in Ukrainian]

8. Vital Signs | Education Commission of the States. URL: http://vitalsigns.ecs.org/state/united-states/demand (accessed 11.08.2019).

9. (2017). Why STEM subjects and democratic citizenship go together. Proceedings from the CESAER conference (19 October 2017). URL: https://ec.europa.eu/commission/commissioners/2014-2019/navracsics/announcements/why-stem-subjectsand-democratic-citizenship-go-together_en Budapest (accessed 11.08.2019).

10. (2018). Global Competitiveness Report 2018 (Reports: World Economic Forum). URL: http://reports.weforum.org/globalcompetitiveness-report-2018/country-economy-profiles/\#economy=UKR (accessed 11.08.2019).

11. Morze, N., Strutynska, O., Umryk, M., (2018). Implementation of robotics as a modern trend in STEM-education. International Journal of Research in E-learning, 4, 2(8), 94-103.

12. Europe 2020. A European strategy for smart, sustainable and inclusive growth. URL: https://ec.europa.eu/ eu2020/pdf/ COMPLET\%20EN\%2OBARROSO\%20\%20\%20007\%20-\%20Europe\%202020\%20-\%20EN\%20version.pdf (accessed 11.08.2019).

13. RT - RoboTeacher. URL: http://www.roboteacher.site (accessed 11.08.2019). [in Ukrainian]

14. Borovyk, D. V., Vovkovinska, N. V., Voichenko O. P. (2017). Prohrama kursu "Tekhnichna tvorchist. Robototekhnika 5-9 klasy" [Program of the course "Technical creativity. Robotics 5-9 classes"]. Kompiuter u shkoli ta simi (Computer at school and family), 3, 12-17. [in Ukrainian]

15. Vasyliuk, A. D., Klymenko, P. O., Nifantiev, K. S. (2018). Prohrama kursu za vyborom "Robototekhnika" dlia uchniv 8-9 klasiv zahalnoosvitnikh navchalnykh zakladiv [The program of the elective course "Robotics" for students of 8-9 classes of general educational institutions]. URL: http://ies.org.ua/wp-content/uploads/2018/08/GRIF_PROG_WEB.pdf (accessed 11.08.2019). [in Ukrainian]

16. Hezalova, M. A. (2013). Navchalna prohrama z pozashkilnoi osvity naukovo-tekhnichnoho napriamu "Osnovy robototekhniky ta komp'iuternoho modeliuvannia" [The on-line tutorial is from out-of-school formation of scientific and technical direction of " Robotics and Computer Modeling"]. Zaporizhzhia, Ukraine, 12. URL: http://www.grani.in.ua/wp-content/ uploads/ 2018/10/ robotech_zrazok.doc (accessed 11.08.2019). [in Ukrainian]

17. Dziuba, S. M., Kit, I. V., Kit, O. H., Michurina, H. V., Khachatrian, S. A. (2013). Navchalna prohrama kursu za vyborom z trudovoho navchannia ta tekhnichnoi tvorchosti dlia 5-9 klasiv zahalnoosvitnikh navchalnykh zakladiv "Tekhnolohiia keruvannia robototekhnichnymy systemamy" [The On-line tutorial of course after a choice from labour studies and technical creation for 5-9 classes of general educational establishments "Technology of management the robototekhnichnimi systems"]. [in Ukrainian]

18. Kit, I. V., Kit, O. H. (2013). Prohrama kursu za vyborom "Proektuvannia robototekhnichnykh system" dlia vyvchennia u 7-9 klasakh [The program of elective course "Designing Robotics Systems" for study in 7-9 classes]. IIETZ Letters from 23.05.2013 № 14.1/12-Г-178. URL: https://drive.google.com/file/d/ OB7_wRGRJlavXV110 V1Zib2t0OWs/ view (accessed 11.08.2019). [in Ukrainian]

19. Кожем'яка Д. І. Навчальна програма курсу за вибором "Основи робототехніки" для вивчення у 5-9 класах. Лист IM30 від 04.12.2015 № 2.1/12-Г-106. К.: Пролего, 2015. URL: http://leader.ciit.zp.ua/files/menu_r2/programs/p_lego.pdf вільний (accessed 11.08.2019). [in Ukrainian]

20. Lysenko, T. I., Shevel, B. O. (2015). Prohrama kursu za vyborom "Osnovy robototekhniky" yak variatyvnoho modulia do navchalnoi prohramy "Tekhnolohii. 10-11 klasy" [Program of course after the choice of "Basis of robototekhniki" as a variant module to the on-line tutorial of "Technology. 10-11 classes"]. IIETZ Letters from 19.02.2015 № 14.1/12-Г-50. URL: http://vynahidnyk.org/files/Doc2.doc (accessed 11.08.2019). [in Ukrainian]

21. Lutsenko, V. Yu. (2015). Vykorystannia zasobiv robototekhniky pry vyvchenni zmistovoi linii "Osnovy alhorytmizatsii ta prohramuvannia" : metodychnyi posibnyk [The use of robotics in the study of the content line "Fundamentals of Algorithmization and Programming": the guide]. MMK, Vinnytsia, Ukraine, 38. [in Ukrainian]

22. Luchkovskyi, A. I., Sokolov, V. A. (2018). Tekhnichna obdarovanist starshoklasnykiv : metodychni rekomendatsii [Technical gifting of high school students: guidelines]. Vyd-vo Instytut obdarovanoi dytyny NAPN Ukrainy, Kyiv, Ukraine, 253. [in Ukrainian]

23. Luchkovskyi, A. I., Sokolov, V. A. (2018). Navchalna prohrama z pozashkilnoi osvity doslidnytsko-eksperymentalnoho 
napriamu "Robototekhnika" [On-line tutorial from out-of-school education research-experimental straight "Robototekhnika"], 77. URL: http://kyiv.man.gov.ua/ upload/2018/ \%D0\%9A\%D0\%B0\%D1 \%80\%D1 \%87\%D0\% B8\%D0\% BD\%D0\%B0/ Robototexnika.pdf (accessed 11.08.2019). [in Ukrainian]

24. (2017). Navchalna prohrama "Tekhnolohii 10-11 klasy" (riven standartu) [On-line tutorial "Technologies 10-11 classes" (level of standard)]. 29 c. URL: https://mon.gov.ua/storage/app/media/zagalna\%20serednya/programy-10-11-klas/20182019/texnologiyi-ostatochnij-variant-10.11.17.docx (accessed 11.08.2019). [in Ukrainian]

25. Shkura, H. A., Nikolaiko, N. Yu. (Ed.) (2018). Navchalni prohramy z pozashkilnoi osvity. Naukovo-tekhnichnyi napriam [Online tutorials are from out-of-school education. Scientific and technical direction]. UDTsPO, Kyiv, Ukraine, Iss. 3, 117. [in Ukrainian]

26. Pakhachuk, C. C., Onishchuk, I. P., Burbel, O. F. (Ed.) (2016). Zbirnyk navchalnykh prohram z pozashkilnoi osvity doslidnytsko-eksperymentalnoho napriamu sektsii "Robototekhnika" [Collection of on-line tutorials from out-of-school education research-experimental straight sections "Robototekhnika"]. Lutsk, Ukraine, 40. [in Ukrainian]

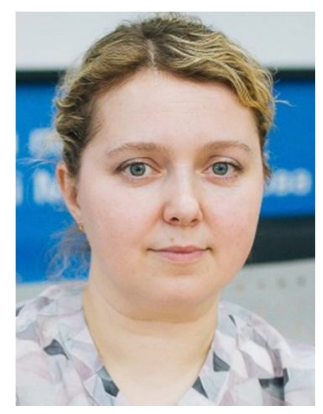

\section{Струтинська Оксана Віталіївна.}

Кандидат педагогічний наук, доцент, доцент кафедри інформаційних технологій і програмування, заступник декана з наукової роботи та міжнародної діяльності факультету інформатики,

Національний педагогічний університет імені М. П. Драгоманова.

вул. Пирогова, 9, м. Київ, Україна, 01601.

Тел. 067-145-64-07.E-mail: o.v.strutynska@npu.edu.ua

\section{Strutynska Oksana Vitaliivna.}

$\mathrm{PhD}$ in Pedagogy, Associated Professor, Department of IT and programming, Vice-Dean of Scientific and International Activities, Faculty of Informatics, National Dragomanov Pedagogical University.

Pyrogova Str., 9, Kyiv, Ukraine, 01601.

Тел. 067-145-64-07 . E-mail: o.v.strutynska@npu.edu.ua

ORCID: 0000-0003-3555-070X

Researcher ID: Y-2358-2019

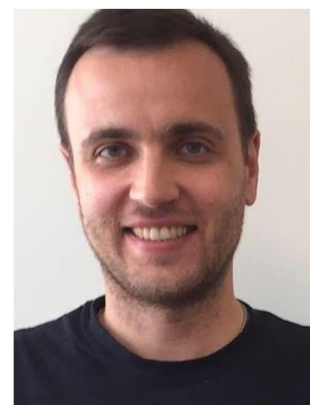

\section{Василюк Анатолій Дмитрович.}

Директор центру ОРТ Єврейського НВК "Щастя", методист відділу розробок і досліджень World ORT FSU. вул. Кибальчича, 3, Київ, Україна, 02183.

Тел. 093-296-71-77 . E-mail: vasiljuktolik@gmail.com

Vasyliuk Anatolii Dmytrovych.

Director ORT RTC \& Jewish State Educational Complex "Simha" (Kyiv),

Specialist World ORT Research \& Development Department for FSU.

Kybaljchycha Str., 3, Kyiv, Ukraine, 02183.

Тел. 093-296-71-77 . E-mail: vasiljuktolik@gmail.com

\section{Citation (APA):}

Strutynska, O., Vasyliuk, A. (2019). Teaching of the Educational Robotics in Ukrainian Schools: the Ways of Implementation. Engineering and Educational Technologies, 7 (3), 122-138. doi: https://doi.org/10.30929/2307-9770.2019.07.03.11

\section{Цитування (ДСТУ 8302:2015):}

Струтинська О. В., Василюк А. Д. Навчання освітньої робототехніки в українських школах: напрями впровадження / ннженерні та освітні технології. 2019. Т. 7. № 3. С. 122-138. doi: https://doi.org/10.30929/2307-9770.2019.07.03.11

Обсяг статmі: сторінок-17 ; умовних друк. аркушів - 2,462. 